\title{
Rural Financial Inclusion: Prospects and Challenges of Collective Action in Extending Financial Services among Rural Smallholders Farmers in Tanzania
}

\author{
Alvin Uronu ${ }^{1}$, Benson Otieno Ndiege ${ }^{2}$ \\ ${ }^{1}$ Department of Extension and Outreach Programmes, Moshi Co-operative University, Moshi, Tanzania \\ ${ }^{2}$ Department of Banking and Finance, Moshi Co-operative University, Moshi, Tanzania
}

Email address:

ndiegebenson@yahoo.com (B. O. Ndiege)

To cite this article:

Alvin Uronu, Benson Otieno Ndiege. Rural Financial Inclusion: Prospects and Challenges of Collective Action in Extending Financial Services Among Rural Smallholders Farmers in Tanzania. International Journal of Agricultural Economics. Vol. 3, No. 2, 2018, pp. 23-30. doi: 10.11648/j.ijae.20180302.11

Received: February 5, 2018; Accepted: March 26, 2018; Published: May 8, 2018

\begin{abstract}
The paper presents prospects and challenges of the collective action in facilitating access to financial services among smallholder farmers in rural areas. It is based on data collected through Focus Group Discussions (FDGs) from 11 cases of Savings and Credit cooperatives (SACCOs), Primary Agricultural Marketing Co-operatives (AMCOS) and Farmers Associations (FA) in Dodoma and Morogoro regions in Tanzania. By using the content analysis, the paper presents three major findings. First, the groups are much relevant in strengthening the ability of the smallholder farmers to access financial services. Second, The majority of smallholder farmers rarely payback their loans obtained through wholesale borrowing. Thus, wholesale group lending results into ineptness which leads to debt frightening. Failure to repay their loans increases financial burden as interest and fine enlarge the loan size. Consequently, frightening cooperation and sustainability of groups and deepening poverty among smallholder farmers. It was further observed that, the main reason for poor repayment of the loans is poor group lending implementation arrangements. Thus, the paper proposes the implementation arrangement of the wholesale lending method that would reduce financial risks and ensure sustainability of the groups.
\end{abstract}

Keywords: Rural Finance, Agriculture, SACCOS, Farmers Associations, Tanzania

\section{Introduction}

In developing countries including Tanzania, the agricultural sector employs more than fifty percent of the people in which most of them are rural smallholder farmers. Implying that, a real development and ending poverty strategies in such countries has to focus on the agricultural sector. Despite this reality, rural agricultural finance (also refered to rural finance) remains a significant challenge for rural development. Only a small proportion of credit goes to small scale farming activities because of high risk and unusually repayment schedules which do not fit the financial requirements (Harper, 2007), especially from formal financial service providers. This scenario, globally, necessitates researchers and policymakers to focus on addressing suitable financial access sources and techniques that would promote rural development (Roberts et al., 2017).
The financial institutions that are working in rural areas have been trying to use group lending model as a solution to agricultural financing risk. The groups are believed to be able to reduce transaction costs and lower the risk of default (Huppi and Feder, 1990). Also, in groups, borrowers have social ties (Freedman and Jin, 2017), which strap up social collateral and produce effective loan repayment rate (De Quidt et al., 2016; Besley and Coate, 1995). Despite the advantages of group lending to the lenders, some previous researchers including Baland et al. (2017) are pessimistic that, group lending does harms the members of the group as well.

There are three issues which literature point out as reasons for adverse effect when group lending model is used in extending rural financial services. Firstly, rural smallholder 
farmers are mostly financially illiterate, and they cannot make a useful financial decision because they lack understanding of simple economic concepts (Mori, 2015). The farmers are not aware of the computations of the interest rates and real costs of their loans (Hastings and Mitchell, 2011). Secondly, farmers are impatient when they have the opportunity to borrow money; the scenario is also termed as a present-bias problem. Present-bias problem is a situation in which farmers choose instant satisfaction instead of captivating benefit from larger long-term payoffs (Hastings and Mitchell, 2011). Lastly, the public gains are low especially when the group is big. According to public goods game theory, the individual motivation to pay the loan is high when public good gains are also higher. However, the public gains decrease as the size of the group increases and when there are no non-credit activities that farmers are involved (Baland et al., 2017). As such management of the groups is not easy as well. That means the use of group lending in extending financial services may both negative and positive effects in the ends.

This paper focused on assessing how useful is the group lending to the rural smallholders farmers in Tanzania. To attain its objective, it studied at ability of groups in facilitating access to financial services. Also, it studied loan repayment ability of borrowers in groups. It uses the common smallholder farmers' group in Tanzania that are working in collective action. That are, Savings and Credit cooperatives (SACCOs), Primary Agricultural Marketing Co-operatives (AMCOS) and Farmers Associations (FA). In so doing, the paper contributes understanding on the effectiveness of group lending among smallholder farmers in rural areas. Then, the paper proposes the implementation arrangement that should be considered when using group lending method as a mean of extending financial services among rural smallholder farmers.

The current paper has been organized into five main parts. From the introduction, the second part is the description of the relevance of the collective action to the rural smallholder farmers proceeded with the methodology, and discussion. In the end, the paper provides conclusion and recommendations to the issues discussed.

\section{Relevance of the Collective Action to the Rural Farmers}

Smallholder farmers in Tanzania are facing numerous challenges at different levels of production, financing, processing to the marketing of their produce (Jayne et al., $2010 ; 2005)$. Specifically, the issues facing these small producers include unreliability, untimely and inappropriateness of the input suppliers. Also, they lack the ability to identifying the ways to add value to their produces since they have inadequate capacities in the post-harvest management and how to link in the value chain marketing (Ruteri, 2009). Also, they have inadequate capacities in finding the right buyer, access to relevant markets and inadequate processing capacities (Markelova et al., 2009). The reason could be that dominant agriculture production techniques are mostly peasantry based on some basic features of mixed farming, shifting cultivation and agro-pastoralist practices (Mtenga, 2006). The smaller or not profitable agriculture activities are due to the farming practices applicable by most of the farmers. Limited access to agricultural finance, less farming enterprises and underutilization of the abundant natural resources, low productivity and the escalating environmental degradation are the regular practices hindering rural agriculture.

Thus, the desire of forming a group is to solve problems afflicting its members jointly. That purpose is to improve living conditions through getting a higher income, getting better services, shared services, financial services, inputs supply, coordinated vaccination, skills generation and others which are necessary to enable individuals to enhance productivity and improved standards of living at the household level (Hellin et al., 2009). Second, there is a motive to come together or to associate with others for learning, solidarity and or social security (Barham and Chitemi, 2009). Hence institutions like farmers organizations become important. Farmer organizations are means for gaining economies of scale that must be controlled and felt by individual members (Fischer and Qaim, 2012). That means their management should focus on providing an interface between the informal producers and the formal systems to the benefit of those in the formal systems. A process of working with farmers to improve their capacity for formation, managing and strengthening services provision groups, requires farmers to have the capabilities to identify and analyze existing resources, opportunities and factors that limit performance.

To solve the farmers' problem require strong institutional framework. It is strongly argued that institutional framework and processes (formal and informal institutions and organizations) have a significant role in coordinating and managing livelihood resources, strategies towards achieving sustainable livelihood outcome (Hellin et al., 2009; Uronu and Liheta 2005). The proper institutional framework is important for the effective group actions. Mtenga (2006) argued that presence of robust organizational framework at individual and group level is instrumental in developing effective linkages between production, financial and marketing and thus prospects for improvement in food security and livelihood. This is because collective actions require a robust institutional framework. Thus, in understanding the challenges also the study looked at the implementation arrangement as a way to understand institutional framework.

\section{Methodology}

The data were from case in Morogoro and Dodoma regions as a part of Market Infrastructure, Value Addition and Rural Finance (MIVARF) programme which is a three years 
program (2016-2018) and financed by the government of Tanzania. Since 2016, Moshi Co-operative University is providing training to build capacity for the Rural Savings and Credit Co-operative Societies (SACCOS), Primary Agricultural Marketing Co-operatives (AMCOS) and Farmers Association (FA) in Tanzania. The program started with needs assessment in collaboration with District Cooperative Officers hence a training program was prepared for the SACCOS Board members based on identified gaps. Data used in this current paper were collected by authors during the backstopping exercise, which aimed to evaluation application of the skills and knowledge provided during training and also identifies new training and non-training gaps. FGDs were used as a data collection method. The authors collected data from the Board members, staffs and ordinary members. A total of Fifteen (15) focus group discussion was conducted in which the number of people in FDGs varies from 5 to 13. However, in some cases when the data were contradicting the researchers inquired for secondary data for validation of the discussion. The secondary data was mainly collected through documentary review.

The cases used, therefore, were selected from SACCOS, AMCOS, and FAs which were under MIVARF programme and have received training on financial issues. Most of the AMCOS and FAs studied were from Morogoro region in Kilombero district. Kilombero is one of the areas which are producing a large quantity of rice in Morogoro and Tanzania. In the Kilombero district, many farmers are members of AMCOS and agricultural associations. In Kilombero and specifically in Mang'ula division there are nine groups which were being supported by MIVARF financial support. These include Msalise AMCOS, Kapolo AMCOS, Mbalaji farmers association, Mugudeni farmers association, Vijana Mbasha association, Muaye farmers association, Bokela farmers association, Mang'ula farmers association and Mkula association (irrigation system). All of the groups depend on rain-fed agriculture except Mkula which is irrigation scheme. In Dodoma, most of the cases used were SACCOS and few AMCOS. Dodoma is one of the dry (low rain) regions which lead to diversification of economic activities. Finally, data were analysed through content analysis and descriptive.

\section{Findings}

All the groups (SACCOS, AMCOS, and FAs) were used because they are used by financial institution to reach individual farmers. Both of these groups are formed by smallholder farmers who own an average of one to ten hectares and $90 \%$ based on rain-fed agriculture as collective actions. SACCOS are financial co-operatives formed to help in mobilizing savings and access loans among members (Kaleshu and Temu, 2012). While SACCOS are financial institutions, their members in the study area were mainly participating in farm's related activities. AMCOS and FA's are agricultural associations/groups that focused on ensuring access to agricultural inputs and market for the crop produces. The main difference between AMCOS and FAs is that AMCOS are registered under cooperative department while associations are registered under the ministry of internal affairs. The membership conditions vary from one group to another, though the difference is tiny. In some areas, AMCOS and SACCOS were formed together in the sense that SACCOS handle the financial matters of the AMCOS. Data have been summarized and presented in two different tables (see Table $1 \& 2$ ) using different cases to reflect, sources of agricultural funds, payment status and implications.

Table 1. Sources of funds for the SACCOS, AMCOS, and FAs

\begin{tabular}{|c|c|c|c|c|c|}
\hline case & District & $\begin{array}{l}\text { SACCOS/AMCOS } \\
/ \text { Fa }\end{array}$ & $\begin{array}{l}\text { Internal } \\
\text { capital (TZS) }\end{array}$ & $\begin{array}{l}\text { External } \\
\text { Financing (TZS) }\end{array}$ & STATUS \\
\hline case 1 & Chamwino & IHEWA & $15,000,000$ & & $\begin{array}{l}\text { Deposited } 16 \mathrm{~m} \text { in bank Ac since } 2013 \text { and they keep waiting for a grape } \\
\text { agricultural finance. No savings made by members and no loans have } \\
\text { been issued to the members. The land and other supportive } \\
\text { infrastructure been supported through DED Chamwino have stalled and } \\
\text { no prospect of continuing }\end{array}$ \\
\hline Case 2 & & Magobwe & $8,000,000$ & & $\begin{array}{l}\text { Members of SACCOS are members of AMCOS which have } 200 \\
\text { acreages of mangoes farm. Members paid one share and kept waiting for } \\
\text { a bank loan }\end{array}$ \\
\hline Case 3 & Mvomero & Wanyamakazi & & $194,000,000$ & $\begin{array}{l}\text { The SACCOS has defaulted loans with three different institutions. SELF } \\
\text { (MF) not paid Sh. } 78,000,000 /=\text { out of Sh. } 100,000,000 /=\text { they } \\
\text { borrowed. } \\
\text { TIB has been repaid Sh. } 82,000,000 /=\text { out of Sh. } 200,000,000 /= \\
\text { MOMVCECO is still expecting Sh. } 34,000,000 /=\text { out of Sh } \\
30,000,000 /=\text { they lent to SACCOS }\end{array}$ \\
\hline Case 4 & & Hembeti & & $60,000,000$ & $\begin{array}{l}\text { Have defaulted loans amounting to } 60,000,000 \text {. They employed } \\
\text { Chimbuko VIKOBA and managed to recoup } 8.0 \mathrm{~m} \text { which has to lead to } \\
\text { open the SACCOS after two years of inactiveness }\end{array}$ \\
\hline Case 5 & Kilombero & KIMAKIM & & & $\begin{array}{l}\text { Became inactive after the failure of members to repay loans secured } \\
\text { from SELF and CRDB. Members suspended board for various } \\
\text { allegations. The SACCOS has started afresh after seven years of } \\
\text { inactiveness }\end{array}$ \\
\hline Case 6 & & UTULIVU & & $13,000,000$ & Defaulted loan from SELF \\
\hline
\end{tabular}

Source: Field data. 
Table 2. Agricultural loan repayment status.

\begin{tabular}{|c|c|c|c|c|c|}
\hline & District & SACCOS/AMCOS/FAs & $\begin{array}{l}\text { Agr Loan } \\
\text { (TZS) }\end{array}$ & $\begin{array}{l}\text { Repayments } \\
\text { (TZS) }\end{array}$ & Status \\
\hline Case 7 & Chamwino & FUNE & $1,500,000,000$ & $720,000,000$ & $2.489 \mathrm{~b}$. Defaulted and rescheduled to 2026 with $5 \%$ interest \\
\hline Case 8 & Mvomero & TurSACCOS & $3,000,000,000$ & $5,000,000,000$ & $\begin{array}{l}\text { 2.0b. still outstanding from the loan which was disbursed in } 2004 \\
\text { Loan disbursed in } 2013 \text { defaulted, employed Debt Collector - }\end{array}$ \\
\hline Case 9 & & Mkusa & $346,000,000$ & & $\begin{array}{l}\text { Chimbuko VIKOBA who managed to collect } 25.0 \mathrm{~m} \text { and paid } \\
\text { themselves fees amounting to } 8.0 \mathrm{~m} \text {. Borrowers have gone to the } \\
\text { court to seek an injunction on the sale of the security }\end{array}$ \\
\hline & Kilombero & & & & Defaulted and last season attempted to seek another loan from \\
\hline Case 10 & & Mugudeni FA & $75,000,000$ & & $\begin{array}{l}\text { Agriculture Bank so that they could offset the Opportunity } \\
\text { outstanding loan and the balance is reinvested in the rice production }\end{array}$ \\
\hline Case 11 & & Mkula FA & & & $\begin{array}{l}\text { Defaulted and employed Debt Collector. Borrowers have gone to } \\
\text { the court to seek an injunction on the sale of the security }\end{array}$ \\
\hline
\end{tabular}

Source: Field data.

\subsection{Collective Action}

Collective action is to action taken jointly by a group of people whose target is to boost their status and achieve a common objective (see e.g. Langergraber et al., 2017; Rivera et al., 2017; Offe and Wiesenthal, 1980). Based on the number of members from SACCOS, AMCOS or FAs in a particular location, it indicates that many people in the study areas believe in collective action. As also shown in previous studies there is cumulative advantages in collective action groups, for stance, strengthen competitiveness (Simpson and Aksoy, 2017). The roles of the groups are in two categories; for self-support and to get support from the government or private institutions. In groups, farmers can raise capital for their agricultural activities. They can develop internal capital using savings and credit schemes such as village community banks (VICOBA) and Savings and Credit Cooperatives Societies (SACCOS).

Moreover, through their registered group, farmers get external agricultural financing (loan) from financial institutions. The financial institutions that available in the study area include CRDB bank, opportunity Bank and SELF. Group of farmers prefers the formal financial institution because they give lump sum money that they can raise from their internal sources. Also, the formal financial institutions would like to do business with the groups because it reduces risk (Ndiege et al., 2014, Kaleshu and Temu, 2012). Normal the association or co-operative become liable for each loan granted to their member. These scenarios show that financial access to the countryside is available mainly when farmers are in groups like co-operatives which are believed to reduce the agricultural risk.

\subsection{Loan Repayment Performance}

Normally the cooperatives or associations receive money from the lender and then distributed to the needy members. In some scenario, we found that the lender give a loan directly to the member of association or co-operative, but the liability remains at the hand of the group. The most important thing is that, the associations or co-operatives are liable for the loan from a lender. They are responsible for collecting loans from its members and pay to the lenders. Once the member does not pay the loan, the association or cooperative is accountable. The experience from the field indicates widely that, the loan borrowed had hardly paid back. As in the tables, from all the cases, none of the SACCOS and Farmers associations which used the external funds given as loan managed to pay the debt on time. For most of these groups, the size of the loan has increased tremendously because the interest rate magnifies.

Various issues identified to be the reasons for poor loan repayment among the members of the group. The previous study including Huppi and Feder (1990) which studies small groups concluded that successful group lending schemes work well with groups that are homogeneous. Based on the theory of group behavior, Cao and Banaji (2017), Kerr (1989) and Fern (1982) for instance, showed that the size of the group is important in explaining the participation, interaction, organization and performance of the group. That is, the bigger the size, the less effective group. This is what seems to be the central issue in the current groups and cooperatives used by the financier in lending rural small scale farmers. Most of these have a big number of members, and it might be that the homogeneity of the group falls as the sizes of the groups are big.

Secondly, Farmers in most cases request a large amount of money than their real need. As noted by Baland et al. (2017), the largest debt leads to the highest rate of default. Typically, small scale farmers do many activities using the family labor (member of the family). The amount of money requested by the farmers need to take into account the difference between the total cost and the value of family labor value when farmers borrow from banks because they just want money. This problem termed as a present-bias problem, whereas they lose the patience (Hastings and Mitchell, 2011). That is, farmers persistently choose instant satisfaction instead of captivating benefit from larger long-term payoffs. Similarly, banks are looking for a business opportunity which also affected by an internal arrangement like a bonus to loan officers who give more loans; they use the impatience of farmers as the opportunity. In such circumstance then, control of the real amount required is not possible. The result is that money is used in other immediate activities and causes a big burden to the borrower in future. 
Thirdly, the money is given to the farm one time for the whole time. It has been observed that all groups which received agricultural loans were given cumulative loan at one time. However, it should be noted that agricultural activity is a process that involves different activities and takes more than four months. Assuming the money is given at the beginning of the season (preparation period), and it covers the all the costs, such as preparation, weeding, harvesting and transportation of produces to the store, home or market. It is evident that it is not an easy task for farmers to keep and manage the money for the whole period of three months or more as assumed by lenders. In this situation, therefore, some farmers search for other money at the middle or the end of the season to for agriculture. The moneylender, friends, and families give them support, whereby farmers have to pay during the harvest. Usually, farmers pay by giving bags of rice. Such trade is made before taking products to the warehouse. Then at the end, the farmer has no enough bags sell and pay back the loan from the bank.

Fourthly, the evaluation of the lenders is not accurate. For instance, Farmers show that the weather was not conducive in many cases and thus affected the production. Consequently, they were unable to repay their loans. Also, the lenders did not comply with internal regulations of the groups. For instance, in most SACCOS, the amount of loan that member can access is one-third of his or her savings. But researchers observed that the loan from the bank did not take into consideration group internal e.g. one-third policy". Literature including Charles and Mori (2017) indicates that proper evaluation of borrowers is significant on loan repayment. Lenders are required to analyze all conditions that may affect the repayment of loans.

Fifthly, farmers are given money when they do not need it and sometimes the amount they did not request for. The researcher observed that, some groups did not get the loan at the time they needed. The loan was released at the time which they were not in farming period. In this situation, there are greater chances that the farmers did not use the money for farming as was planned.

Sixthly, the farmers and members of SACCOS have limited financial literacy. According to Mori et al. (2017), financial illiteracy is higher in the rural areas, and this is observed in this study. In TURSACCOS for example, the board members showed that they need financial and legal experts to advise them as they have the sense that the outstanding loan was not correct. Their assumption may or may not be correct. It highly possible that big loan was the results of a compound interest rate because they did not pay as per the schedule. As was also noted by the parallel with Hastings and Mitchell (2011) there is a problem of understanding of easy economic concepts and cannot carry out computations such as computing compound interest, which could cause them to make sub-optimal financial decisions. This implies that most of the small scale farmers are not aware of how debt works and therefore they realize the impacts after during the payments. There are two important points noted (1) SACCOS members fail to identify where they should invest and they have a weak business environment that limits their ability to repay debt. From the observation, we understand that most of the business done by members of the SACCOS are agricultural related. These are vulnerable activities that have a high level of uncertainty. (2) Both Members of SACCOS and board members are financially illiterate. In fact, more than half of the SACCOS cannot employ a specialist. Management has limited ability to scrutinize worth credit members and in most cases cannot forecast the credit risk for the loans. Members have limited knowledge on why they should save in SACCOS. They save money to get a loan.

Lastly, the farmers are taking the loans as the gift. As the size of the group is increasing members the control is difficult, and members tend to free ride. We observed in discussions that the farmers were lamenting bitterly when they requested for loans and was not granted. Actually there were not talking or thinking on the difficulty arises on loan refunding but insisting on getting more loans. As also indicated by Baland et al. (2017), high rate of default is likely when there is small loans and group is big which lowers noncredit joint activities among members.

Based on the findings it seems that the size of membership increases the difficulty in managing the groups and this, therefore, leads to poor loan repayment. It was also observed that members receive the loan as a gift or they feel responsible for loans they take. They normally chose to abandon groups than paying their dues. Lastly, most of the rural residences are financially illiterate. For example, they receive loans even when they are not ready or not productive period, and they end up losing the money.

\subsection{Lesson Learnt}

Based on these findings, there are three important issues to consider when supporting groups regarding financial loans. Firstly, proper evaluation of the important group characteristics that should be considered by the supporting organizations, FIs and other actors intending to collaborate with the groups to carry out due diligence to establish the status of the group. Table 3 summarises the proposed basic characteristics that could be considered before provision of financial loans to groups. The components that need to be assessed include the purpose of the group, structure of the system and nature of people (members). In all these three criteria the groups categorized into four groups levels which are an Unstable group, Learning group, Developing group and Pre-cooperative enterprise. The last pre-cooperative enterprise will be less risky and unstable group will be much riskier. This observation is congruent to the Barham and Chitemi (2009) whose findings suggested that more mature groups which have strong internal institutions, functioning group activities, and also a good asset base of natural capital might be more likely to improve their market situation.

Secondly, training on financial literacy is important to the rural small scale farmers. It appears that most financial take for granted that group members have enough knowledge that allows them to manage their loans. However, the higher level 
of nonperforming loan among smallholder farmers is low financial literacy among them.

Table 3. Characteristics of groups.

\begin{tabular}{|c|c|c|}
\hline Component assessed & Unstable group & Learning group \\
\hline Purpose & $\begin{array}{l}\text { Purpose of accessing funds and training for one economic } \\
\text { activity. No common goal. }\end{array}$ & $\begin{array}{l}\text { Main current purpose of the group is to learn about an agricultural/ } \\
\text { livestock activity, good practices and to get started; } \\
\text { To have better access to information and supervision/ advice/ } \\
\text { assistance from other members of the Group and extension officers; } \\
\text { Not 'self-sufficient' yet }\end{array}$ \\
\hline $\begin{array}{l}\text { Structures and } \\
\text { Systems }\end{array}$ & $\begin{array}{l}\text { Financial and decision transparency is weak } \\
\text { Constitution and business plan not internalized or used, weak } \\
\text { or no bookkeeping - very weak accountability } \\
\text { Often new groups with weak cohesion and weak internal } \\
\text { confidence. }\end{array}$ & $\begin{array}{l}\text { Meet on occasion of the presence of extension officer } \\
\text { Weakly developed plans for future } \\
\text { Genuine efforts for transparent record keeping (activities, financial), } \\
\text { but very basic and no records on sales/ profits/ incomes } \\
\text { Constitution not yet fully adapted to activities and roles } \\
\text { (responsibilities of members? Responsibilities of EG? ) }\end{array}$ \\
\hline People & $\begin{array}{l}\text { Attendance meetings weak and dropouts high } \\
\text { Fall apart when negative external trends/events (diseases, } \\
\text { drought, etc.) } \\
\text { Weak supervision by the group (and weak leadership) } \\
\text { Weak division of roles and responsibilities } \\
\text { Weak contribution by the members } \\
\text { Illiterate, poor resource }\end{array}$ & $\begin{array}{l}\text { Satisfactory supervision of the group and growing cohesion and } \\
\text { leadership } \\
\text { No or very small contributions (in cash) to the group, but starting. } \\
\text { No clear idea on the future use of own contributions (if any). }\end{array}$ \\
\hline
\end{tabular}

Table 3. Continued.

\begin{tabular}{|c|c|c|}
\hline Component assessed & Developing group & Pre-Cooperative enterprise \\
\hline Purpose & $\begin{array}{l}\text { Start to develop collective services to add value to individual } \\
\text { activities of members (marketing, inputs, rent material), others } \\
\text { than learning } \\
\text { Re-invest in agriculture, small productive activities } \\
\text { Individual adaptation rate high, with a clear goal to build } \\
\text { additional income }\end{array}$ & $\begin{array}{l}\text { These groups run a pre-cooperative enterprise already but often } \\
\text { get stuck on important steps to improve marketing or processing } \\
\text { or to expand (investments, quality control, and certification, } \\
\text { linkages) } \\
\text { Profits are reinvested in the enterprise, some of it used in the } \\
\text { internal credit system. } \\
\text { Employment of members is (partially) paid by the group. } \\
\text { The expansion is within reach. }\end{array}$ \\
\hline Structures and Systems & $\begin{array}{l}\text { Often have developed an internal/ informal credit and saving } \\
\text { scheme, minority linked to SACCOS } \\
\text { Transparent use exercise book for bookkeeping but not fully } \\
\text { correct } \\
\text { Try to improve their original business plan but don't always } \\
\text { succeed. } \\
\text { Have a clear idea of the profitability of their future enterprise. } \\
\text { Often existed as a group before (even social group) }\end{array}$ & $\begin{array}{l}\text { Often have developed an internal credit and saving scheme not } \\
\text { necessarily linked to SACCOS/ MFI } \\
\text { Transparent bookkeeping } \\
\text { A business plan is basic but correct but not always correctly } \\
\text { used }\end{array}$ \\
\hline People & $\begin{array}{l}\text { Have clear vision on the future role of the group and members } \\
\text { and vice versa, but have not always implemented it fully } \\
\text { Have assets and have built up capital via contributions of } \\
\text { members (stable contributions) }\end{array}$ & $\begin{array}{l}\text { Have a clear vision on the future development of their enterprise } \\
\text { Strong leadership and cohesion } \\
\text { Members contribute and gain employment }\end{array}$ \\
\hline
\end{tabular}

Source: researchers' design.

Thirdly, the loan needs to be the right amount required by the farmer to finance inputs and manpower that cannot be covered at the family level. Most important the loan should be given in installments based on the period/stage of production. Table 4 gives an example of the possible breakdown of the farmer of the loan as per production period/phase.

Table 4. Example of possible activity based agricultural loans.

\begin{tabular}{lllll}
\hline Farming activities & Period & cost per hectare (TZS) & Quantity (hectare) & Amount requested \\
\hline Preparation of the land & January & 50,000 & 2 & 100,000 \\
Seeds & February & 12,000 & 5 & 60,000 \\
Weeding & March & 70,000 & 2 & 140,000 \\
Pesticides & April & 30,000 & 5 & 150,000 \\
Fertilizer & April & 20,000 & 5 & 100,000 \\
Harvesting and transportation & July & 30,000 & 5 & 150,000 \\
Total & & & 700,000 \\
\hline
\end{tabular}

Source: researchers' design.

The assumptions here is that, firstly, the farmer will use the money for the right activity. Secondly, the loan officers have time to satisfy themselves whether the previous money has been used correctly. Otherwise, they stop releasing more 
money. Moreover, the farmer may change the plan, and in that case, he/she will not need more money and thus avoid unnecessary burden.

\section{Conclusion}

The paper examined two issues; firstly, the relevance of the collective action in extending financial accesses among smallholder farmers. Secondly, the study examines the challenges emanated from group landings among smallholder farmers. The results show that many smallholders farmers in the study areas accesses agricultural funds through their groups. However, the overburden problem is a common situation to many SACCOS, AMCOS and FAs. The paper is in agreement with previous researchers that this problem is a results of number of issues that can be summarised as poor knowledge of financial matters (financial illiteracy), impatient (present-bias problem) among farmers and thinking that loans are a gift (public good game) are the reasons. Thus, from the results the main problem is poor wholesale lending implementation and arrangements.

The level of debt is frightening. SACCOS, AMCOS and FAs live and die and, therefore, not entrust by members themselves. Many groups lose their bindings and become inactive or disintegrate completely. After the first loan, the future productivity is affected. This is because the farmers can hardly get a loan from the same or other financial institutions. Also, they are required to produce to pay the previous loan. Thus, though the linkage between financial institutions and groups of poor is necessary for Poverty reduction, that the opposite is also true. These results are relevant to inform the policy makers and government and non-government institutions that work to improve rural economy including agricultural productivity $\mathrm{n}$ the long-term impact of the groups.

Finally, the paper proposes the implementation arrangement of the wholesale lending method that would reduce financial risks among smallholder farmers to be based on a keen assessment of the group which should focus on the purpose of the group, structure and system and the nature of the people. These should help assessor to define the group into the deferent level of development like the unstable group, learning group, developing the group, pre-cooperative enterprise. In such case, the assessor will be in a position to advise on how to provide financial services that would bring sustainable development of the group and its members. It would be more scientific if proposed implementation arrangements are tested.

\section{References}

[1] Ahmad, Z., Abdullah, N. M. H., \& Roslan, S. (2012). Capital Structure Effect on Firms Performance: Focusing on Consumers and Industrials Sectors on Malaysian Firms. International Review of Business Research Papers, 8 (5), 137-155.

[2] Baland, J. M., Gangadharan, L., Maitra, P., \& Somanathan, R.
(2017). Repayment and exclusion in a microfinance experiment. Journal of Economic Behavior \& Organization, 137, 176-190.

[3] Barham, J., \& Chitemi, C. (2009). Collective action initiatives to improve marketing performance: Lessons from farmer groups in Tanzania. Food policy, 34 (1), 53-59.

[4] Besley, T., \& Coate, S. (1995). Group lending, repayment incentives and social collateral. Journal of development economics, 46 (1), 1-18.

[5] Cao, J., \& Banaji, M. R. (2017). Social inferences from group size. Journal of Experimental Social Psychology, 70, 204-211.

[6] Charles, G., \& Mori, N. (2017). Loan repayment performance of clients of informal lending institutions: do borrowing histories and dynamic incentives matter?. International Journal of Development Issues, (just-accepted), 00-00.

[7] De Quidt, J., Fetzer, T., \& Ghatak, M. (2016). Group lending without joint liability. Journal of Development Economics, $121,217-236$

[8] Fern, E. F. (1982). The use of focus groups for idea generation: the effects of group size, acquaintanceship, and moderator on response quantity and quality. Journal of Marketing Research, 1-13.

[9] Fischer, E., \& Qaim, M. (2012). Linking smallholders to markets: determinants and impacts of farmer collective action in Kenya. World Development, 40 (6), 1255-1268.

[10] Freedman, S., \& Jin, G. Z. (2017). The information value of online social networks: lessons from peer-to-peer lending. International Journal of Industrial Organization, 51, 185-222.

[11] Harper, M. (2007). Microfinance and farmers: Do they fit?. In What's Wrong with Microfinance? (Vol. 83, No. 94, pp. 8394). Practical Action Publishing in association with GSE Research.

[12] Hastings, J. S., \& Mitchell, O. S. (2011). How financial literacy and impatience shape retirement wealth and investment behaviors (No. w16740). National Bureau of Economic Research.

[13] Hellin, J., Lundy, M., \& Meijer, M. (2009). Farmer organization, collective action and market access in MesoAmerica. Food Policy, 34 (1), 16-22.

[14] Huppi, M., \& Feder, G. (1990). The role of groups and credit cooperatives in rural lending. The World Bank Research Observer, 5 (2), 187-204.

[15] Jayne, T. S., Mather, D., \& Mghenyi, E. (2005). Smallholder farming in difficult circumstances: Policy issues for Africa. The Future of Small Farms, 103.

[16] Jayne, T. S., Mather, D., \& Mghenyi, E. (2010). Principal challenges confronting smallholder agriculture in sub-Saharan Africa. World development, 38 (10), 1384-1398.

[17] Kaleshu, J., \& Temu, S. (2012). Expansion of rural financial services through linkage banking in Tanzania: Is joint action between savings and credit cooperative societies (SACCOS) a promising approach? Enterprise Development and Microfinance, 23 (2), 146-160.

[18] Kerr, N. L. (1989). Illusions of efficacy: The effects of group size on perceived efficacy in social dilemmas. Journal of experimental social psychology, 25 (4), 287-313. 
[19] Langergraber, K. E., Watts, D. P., Vigilant, L., \& Mitani, J. C. (2017). Group augmentation, collective action, and territorial boundary patrols by male chimpanzees. Proceedings of the National Academy of Sciences, 114 (28), 7337-7342.

[20] Markelova, H., Meinzen-Dick, R., Hellin, J., \& Dohrn, S. (2009). Collective action for smallholder market access. Food policy, 34 (1), 1-7.

[21] Mori, N., Nyantori, T., \& Olomi, D. (2017). Effects of clients' literacy on default and delinquency of savings and credit cooperative societies in Tanzania. Business Management Review, 19 (2), 1-12.

[22] Ndiege, B. O., Qin, X., Kazungu, I., \& Moshi, J. (2014). The impacts of financial linkage on sustainability of less-formal financial institutions: experience of savings and credit cooperative societies in Tanzania. Journal of Co-operative Organization and Management, 2 (2), 65-71.
[23] Offe, C., \& Wiesenthal, H. (1980). Two logics of collective action: Theoretical notes on social class and organizational form. Political power and social theory, 1 (1), 67-115.

[24] Rivera, V. S., Cordero, P. M., Rojas, D. C., \& O’Riordan, B. (2017). Institutions and collective action in a Costa Rican small-scale fisheries cooperative: the case of CoopeTárcoles RL. Maritime Studies, 16 (1), 22.

[25] Ruteri, J. M. (2009). Supply chain management and challenges facing the food industry sector in Tanzania. International Journal of Business and Management, 4 (12), 70 .

[26] Simpson, B., \& Aksoy, O. (2017). Cumulative advantage in collective action groups: How competition for group members alters the provision of public goods. Social Science Research. 